\title{
Pengaruh Pemberian Auksin (NAA) dengan Sitokinin (BAP, Kinetin dan 2ip) terhadap Daya Proliferasi Tanaman Kantong Semar (Nepenthes mirabilis) Secara In Vitro
}

\section{The Effect of Auxin (NAA) and Cytokinin (BAP, Kinetin and 2iP) on in vitro Growth of Tropical Pitcher Plant (Nepenthes $\underline{\text { mirabilis) }}$}

\section{Agus Setyo Yudhanto dan Ni Made Armini Wiendi*}

Departemen Agronomi dan Hortikultura, Fakultas Pertanian, Institut Pertanian Bogor (Bogor Agricultural University), J1. Meranti, Kampus IPB Darmaga, Bogor 16680, Indonesia Telp. \& Faks. 62-251-8629353 e-mail agronipb@indo.net.id *Penulis Korespondensi : nmarmini@gmail.com

Disetujui : 14 November 2015 / Published online 12 Desember 2015

\begin{abstract}
Auxin and sitokinin are usually used as in vitro plant growth regulators. Combination of auxin (NAA) with sitokinin (BAP, kinetin, and 2ip) on in vitro bud proliferation of Nepenthes mirabilis was find out. This research were designed using completely randomized design with two factors, auxin as a first factor and cytokinin as second factor. The combination of auxin and cytokinin used was NAA: 1 and $2 \mathrm{mg} / \mathrm{l}$ while BAP, kinetin, and 2ip was respectively as much as $0,2.5$, and $5 \mathrm{mg} / \mathrm{l}$. The combination of growth regulator that added to Murashige and Skoog (MS) medium. The best result for bud proliferation was no sitokinin and additional NAA $1 \mathrm{mg} / \mathrm{l}$ as much as 5.2 buds in 10 weeks.
\end{abstract}

Keywords: 2ip, BAP, in vitro, kinetin, NAA, Nepenthes mirabilis, shoot proliferation

\begin{abstract}
ABSTRAK
Auksin dan sitokinin umumnya digunakan sebagai zat pengatur tumbuh secara in vitro. Sudah ditemukan bahwa kombinasi auksin (NAA) dan sitokinin (BAP, kinetin, dan 2ip) untuk proliferasi tunas Nepenthes mirabilis secara in vitro. Penelitian ini dirancang menggunakan rancangan acak lengkap dua faktor, auksin sebagai faktor pertama dan sitokinin sebagai faktor kedua. Kombinasi auksin dan sitokinin yang digunakan adalah NAA: 1 dan $2 \mathrm{mg} / \mathrm{l}$ sedangkan BAP, kinetin, dan 2ip masing-masing sebanyak 0 , 2,5, dan $5 \mathrm{mg} / \mathrm{l}$. Kombinasi zat pengatur tumbuh yang ditambahkan ke media Murashige dan Skoog (MS). Hasil terbaik untuk proliferasi tunas yaitu perlakuan tanpa sitokinin dan tambahan NAA $1 \mathrm{mg} / \mathrm{l}$ sebanyak 5,2 tunas dalam 10 minggu.
\end{abstract}

Kata kunci: 2ip, BAP, in vitro, kinetin, NAA, Nepenthes mirabilis, proliferasi tunas 


\section{PENDAHULUAN}

Indonesia adalah negara kepulauan yang berada pada garis khatulistiwa yang merupakan salah satu negara tropis di dunia. Sebagai negara tropis, Indonesia memiliki berbagai jenis flora dan fauna endemik yang tidak dimiliki oleh negara atau tempat lain di bagian dunia ini. Salah satu flora endemik yang hanya tumbuh di Indonesia adalah tanaman kantong semar (Nepenthes sp.). Keberadaan Nepenthes sp. termasuk spesies langka dan dilindungi oleh negara maupun dunia. Sebagai tanaman yang dilindungi maka perdagangan internasional tanaman yang berasal dari habitat alam harus dikontrol dengan ketat dan hanya diperkenankan untuk kepentingan non komersial tertentu dengan izin khusus.

Menurut Phillip dan Lamb (1996) Nepenthes merupakan satu-satunya genus dari famili Nepenthaceae. Kurang lebih terdapat 83 spesies yang saat ini telah teridentifikasi tersebar di dunia dan 53 spesies diantaranya $(>60 \%)$ terdapat di Indonesia. Kalimantan menempati urutan pertama dengan jumlah Nepenthes lebih dari 29 jenis. Berdasarkan hasil penelusuran spesimen di Herbarium Bogor, ditemukan bahwa di Sulawesi terdapat minimum 10 jenis, New Guinea 9 jenis, Maluku 4 jenis, dan Jawa hanya terdapat 2 jenis Nepenthes saja.

Keunikan tanaman ini dapat dilihat dari bentuk dan struktur khas yang menjadikan daya tarik tersendiri. Morfologi kantong beraneka ragam, merupakan modifikasi daun, berfungsi sebagai perangkap serangga terutama semut dan dedaunan. Dalam kantong terdapat cairan berupa enzim yang dapat menghancurkan bagian-bagian tubuh serangga dan dedaunan sehingga menjadi sumber nutrisi untuk pertumbuhan tanaman ini. Selain bentuk yang beraneka ragam, ukuran dan warna kantong yang bervariasi sesuai dengan tempat tumbuh dan jenisnya menambah daya tarik tanaman (Mansur, 2006).

Salah satu metode perbanyakan tanaman yang dapat ditempuh yaitu melalui kultur in vitro. Metode ini diharapkan mampu menghasilkan tanaman dalam skala besar dengan waktu yang relatif cepat serta kualitas tanaman yang dihasilkan menjadi lebih baik. Menurut Gunawan (1992), melalui kultur jaringan kebutuhan ketersediaan bibit tanaman dalam skala besar dapat terpenuhi. Sundorowati et al. (2002) juga menambahkan bahwa perbanyakan tanaman dengan teknik kultur jaringan (in vitro) telah banyak dilakukan untuk tanaman yang bernilai ekonomi tinggi atau tergolong langka dan sulit dipropagasi dengan cara konvensional.
Penelitian tentang pengaruh media terhadap pertumbuhan dan perkembangan nepenthes mirabilis secara in vitro telah dilakukan sebelumnya oleh Sayekti (2007) dan Alitalia (2008). Menurut Sayekti (2007) media perkecambahan nepenthes terbaik adalah $1 / 4 \mathrm{KC}$ dan $1 / 2$ MS. Pada penelitian ini juga diperoleh tanaman yang membentuk kalus dan multiplikasi tunas pada minggu ke-8 setelah berkecambah. Media yang mampu memberikan respon pertumbuhan tersebut adalah $1 / 4 \mathrm{KC}+$ Thidiazuron (TDZ) dan $1 / 2 \mathrm{MS}+$ TDZ. Pertumbuhan tanaman pada media ini berbeda dengan yang lain. Tanaman menjadi kerdil (abnormal), daun tidak berkantong, roset, berukuran kecil dengan jumlah yang banyak. Hal ini disebabkan oleh aktivitas TDZ sebagai sitokonin yang sangat aktif walaupun dalam konsentrasi yang sangat rendah. Penelitian bertujuan untuk mempelajari pengaruh kombinasi auksin (NAA) dengan sitokinin (BAP, kinetin dan 2iP) terhadap pertumbuhan tunas dan akar (ploriferasi) Nepenthes mirabilis secara in vitro.

\section{BAHAN DAN METODE}

Penelitian dilaksanakan di Laboraturium Bioteknologi Tanaman, Departemen Agronomi dan Hortikultura, Fakultas Pertanian, Institut Pertanian Bogor, pada bulan Juni - Oktober 2010.

Bahan tanaman digunakan eksplan Nepenthes mirabilis steril yang telah ditanam pada media $1 / 2$ MS dan telah berumur \pm 1.5 tahun sejak dikecambahkan.. Bahan untuk media tanam meliputi Zat Pengatur Tumbuh NAA 1 dan $2 \mathrm{mg} / \mathrm{l}$ (auksin), BAP, Kinetin dan 2iP masing-masing 0, 2.5 , dan $5 \mathrm{mg} / \mathrm{l}$ (sitokinin), larutan stok MS, agaragar $8 \mathrm{~g} / \mathrm{l}$, gula pasir $30 \mathrm{~g} / \mathrm{l}$ dan aquades. Pengaturan $\mathrm{pH}$ media dengan menambahkan $\mathrm{KOH}(1 \quad \mathrm{~N})$ atau $\mathrm{HCl}(1 \mathrm{~N})$. Bahan yang digunakan untuk sterilisasi berupa alkohol $70 \%$. Bahan lain yang digunakan antara lain aquadest, karet gelang, plastik, tissue, spirtus dan label.

Alat-alat yang digunakan antara lain botol kultur, pipet, cawan petri, labu takar, bunsen, erlenmeyer, sprayer, mata pisau, scalpel, timbangan, gunting, pinset, autoclaf dan laminar air flow cabinet. Rak penyimpanan dilengkapi dengan lampu fluorescence dengan intensitas cahaya antara 500-750 lux sebagai sumber penyinaran dengan suhu ruangan diatur antara $20^{\circ} \mathrm{C}-22^{\circ} \mathrm{C}$.

Penelitian ini menggunakan metode Rancangan Acak Lengkap (RAL), dengan dua faktor yaitu perbandingan konsentrasi auksin dengan konsentrasi sitokinin. Faktor pertama yaitu konsentrasi auksin berupa 1 dan $2 \mathrm{ppm}$ 
NAA, sedangkan faktor kedua yaitu jenis dan konsentrasi sitokinin berupa BAP, kinetin dan 2 iP masing-masing 0, 2.5 dan $5 \mathrm{ppm}$.

Pelaksanaan

Sterilisasi Alat dan Botol. Sterilisasi merupakan faktor terpenting dari keberhasilan pelaksanaan kultur jaringan. Alat-alat dan botol yang akan digunakan dalam pembuatan media dan penanaman dicuci hingga bersih kemudian disterilkan dengan menggunakan autoklaf selama satu jam pada suhu $121^{\circ} \mathrm{C}$ dan tekanan 17.5 psi. Perhitungan lama waktu dimulai ketika tekanan telah berada pada 17.5 psi selama satu jam. Alat yang perlu disterilkan antara lain pinset, botol kultur, kertas saring, scalpel, cawan petri, dan pengaduk.

Pembuatan Larutan Stok. Pembuatan larutan stok dilakukan sebelum pembuatan media tanam bertujuan untuk memudahkan dalam pencampuran media kultur. Media yang dibuat terdiri dari media Murashige Skoog (MS). Larutan stok dibuat sesuai dengan komposisi media MS yang disimpan dalam erlenmeyer dengan konsentrasi yang lebih pekat. Beberapa jenis larutan stok media MS tahan disimpan di ruangan dengan suhu ruang tetapi adapula yang harus disimpan dalam lemari es. Larutan stok F, myoinositol dan vitamin disimpan dalam lemari es, sedangkan larutan stok A,B,C,D dan E dapat disimpan dalam suhu ruang.

Pembuatan Media Kultur. Media kultur yang digunakan dalam penelitian ini adalah media MS. Media MS dibuat dengan memipet $20 \mathrm{ml}$ larutan stok A, B dan vitamin, $5 \mathrm{ml}$ larutan stok C, $\mathrm{D}$ dan $\mathrm{E}, 10 \mathrm{ml}$ larutan $\mathrm{F}$ dan Myoinositol ke dalam labu takar satu liter (Tabel Lampiran 1). Setelah itu ditambahkan NAA sebanyak $1 \mathrm{ml}$ untuk mendapatkan media dengan konsentrasi $1 \mathrm{mg} / \mathrm{l}$ dari stok $1 \mathrm{~g} / \mathrm{l}$ NAA dan BAP sebanyak $1 \mathrm{ml}$ untuk mendapatkan media dengan konsentrasi $1 \mathrm{mg} / \mathrm{l}$ dari stok 1g/l BAP. Kemudian gula dilarutkan sebanyak $30 \mathrm{~g}$ kedalam aquades dan dicampurkan ke dalam larutan media. Masukkan aquadest hingga tanda terra 1 liter. Untuk mengukur kemasaman media digunakan $\mathrm{pH}$ meter 5,8 diatur dengan menambahkan $\mathrm{KOH}$ atau $\mathrm{HCl}$. Larutan media yang telah siap dipindahkan ke dalam panci pemanas lalu ditambahkan agar-agar sebanyak 8 gram. Larutan media tersebut dipanaskan sambil diaduk-aduk hingga mendidih. Botol-botol kultur yang telah steril disiapkan untuk diisi dengan larutan media yang telah dipanaskan. Larutan media agar yang telah mendidih dituangkan ke dalam botol-botol kultur yang telah disediakan. Botol-botol yang telah diisi dengan larutan media agar sama rata ditutup rapat dengan plastik transparan. Botolbotol yang telah tertutup plastik dengan baik disterilkan dengan autoklaf pada suhu $121^{\circ} \mathrm{C}$ dan tekanan 17.5 psi selama 20 menit. Media steril disimpan dalam ruang kultur. Media ini dapat digunakan setelah inkubasi selama 4 hari dan bebas dari kontaminasi.

Persiapan Ruang Tanam. Ruang tanam yang digunakan sebagai tempat menanam eksplan atau yang biasa disebut laminar air flow cabinet. Sebelum digunakan terlebih dahulu dibersihkan dengan menggunakan alkohol $96 \%$ dan disterilkan dengan sinar ultra violet selama $1 \mathrm{jam}$. Alat tanam dan bahan-bahan yang akan digunakan disemprot alkohol $70 \%$ sebelum di masukkan ke dalam laminar air flow cabinet. Hal ini dilakukan untuk menghindari resiko bahan penelitian terkontaminasi.

Penanaman. Eksplan tunas Nepenthes mirabilis diperoleh dari biji yang telah ditanam \pm 1.5 tahun sejak dikecambahkan. Eksplan dipilih dari dalam botol yang memiliki penampilan baik, seperti pertumbuhan optimum, daun hijau tua, tidak berwarna kuning, tidak vitrus, tidak kekurangan hara dan tidak berkalus. Eksplan diambil dari tunas yang dipotong dari pangkal batang tanpa akar, tiap potongan berukuran 1-1.5 $\mathrm{cm}$ dan tanpa pemotongan tunas apikal. Potongan kecil ini kemudian ditanam di media perlakuan. Setiap botol kultur terdiri dari 3 eksplan. Botol kultur yang telah ditanami diletakkan di rak dalam ruang kultur di bawah cahaya penuh.

Pemeliharaan. Pemeliharaan dilakukan dengan pengontrolan harian maupun mingguan. Botol kultur harus tetap dalam keadaan bersih dan dihindarkan dari media yang terkontaminasi. Penyemprotan alcohol $70 \%$ dilakukan tiap minggu dan penggantian tutup botol jika tutup botol yang lama telah rusak. Kondisi ruang kultur dipertahankan antara $20-22{ }^{\circ} \mathrm{C}$. Intensitas cahaya dipertahankan pada 500-750 lux dengan pencahayaan selama 16 jam penuh.

Pengamatan. Pengamatan dilakukan selama 10 minggu. Pengamatan dilakukan setiap minggu. Peubah yang diamati antara lain:

1. Persentase kontaminasi

2. Presentase hidup

3. Warna tanaman

4. Jumlah tunas

5. Jumlah daun

6. Jumlah akar 

7. Jumlah kantong
10. Waktu inisiasi daun
8. Waktu inisiasi akar
11. Waktu inisiasi kantong
9. Waktu inisiasi tunas

HASIL DAN PEMBAHASAN

\section{Kondisi Umum}

Tabel 1. Rekapitulasi sidik ragam respon peubah yang diamati pada kultur Nepenthes mirabilis secara in vitro

\begin{tabular}{|c|c|c|c|c|}
\hline \multirow[b]{2}{*}{ Peubah } & \multicolumn{3}{|c|}{ Perlakuan } & \multirow[b]{2}{*}{$\mathrm{KK}(\%)$} \\
\hline & NAA & Sitokinin & $\begin{array}{c}\text { NAA* } \\
\text { Sitokinin }\end{array}$ & \\
\hline Inisiasi Akar & tn & $*$ & $\operatorname{tn}$ & 30.539 \\
\hline Inisiasi Daun & tn & $*$ & tn & 13.931 \\
\hline Inisiasi Kantong & $\operatorname{tn}$ & tn & $\operatorname{tn}$ & 21.607 \\
\hline Inisiasi Poriferasi & th & th & th & 19.789 \\
\hline Tunas & th & tn & th & \\
\hline \multicolumn{5}{|l|}{ Jumlah Akar } \\
\hline $2 \mathrm{MST}$ & tn & tn & tn & 2.697 \\
\hline $4 \mathrm{MST}$ & tn & tn & tn & 8.320 \\
\hline $5 \mathrm{MST}$ & $\operatorname{tn}$ & $*$ & $\operatorname{tn}$ & 11.298 \\
\hline $6 \mathrm{MST}$ & tn & $*$ & tn & 13.841 \\
\hline $7 \mathrm{MST}$ & tn & $* *$ & tn & 16.389 \\
\hline $8 \mathrm{MST}$ & $\operatorname{tn}$ & $*$ & $\operatorname{tn}$ & 19.475 \\
\hline $9 \mathrm{MST}$ & tn & $* *$ & tn & 20.986 \\
\hline $10 \mathrm{MST}$ & $\operatorname{tn}$ & $*$ & $\operatorname{tn}$ & 22.538 \\
\hline \multicolumn{5}{|l|}{ Jumlah Daun } \\
\hline $2 \mathrm{MST}$ & $\operatorname{tn}$ & tn & $\operatorname{tn}$ & 8.030 \\
\hline $4 \mathrm{MST}$ & tn & tn & tn & 13.590 \\
\hline $5 \mathrm{MST}$ & tn & tn & $\operatorname{tn}$ & 13.046 \\
\hline $6 \mathrm{MST}$ & tn & tn & tn & 15.913 \\
\hline $7 \mathrm{MST}$ & tn & tn & $\operatorname{tn}$ & 17.171 \\
\hline $8 \mathrm{MST}$ & tn & tn & tn & 17.161 \\
\hline $9 \mathrm{MST}$ & tn & tn & $\operatorname{tn}$ & 17.160 \\
\hline $10 \mathrm{MST}$ & $\operatorname{tn}$ & tn & tn & 17.211 \\
\hline \multicolumn{5}{|l|}{ Jumlah Kantong } \\
\hline $2 \mathrm{MST}$ & tn & tn & $\operatorname{tn}$ & 7.577 \\
\hline $4 \mathrm{MST}$ & tn & tn & $\operatorname{tn}$ & 13.128 \\
\hline $5 \mathrm{MST}$ & tn & tn & tn & 12.089 \\
\hline $6 \mathrm{MST}$ & $\operatorname{tn}$ & tn & $\operatorname{tn}$ & 14.608 \\
\hline $7 \mathrm{MST}$ & tn & tn & tn & 16.525 \\
\hline $8 \mathrm{MST}$ & $\operatorname{tn}$ & tn & $\operatorname{tn}$ & 17.028 \\
\hline 9 MST & tn & tn & tn & 17.464 \\
\hline $10 \mathrm{MST}$ & tn & tn & tn & 18.214 \\
\hline \multicolumn{5}{|l|}{ Jumlah Tunas } \\
\hline $2 \mathrm{MST}$ & tn & tn & tn & 14.337 \\
\hline $3 \mathrm{MST}$ & tn & tn & $\operatorname{tn}$ & 13.757 \\
\hline $4 \mathrm{MST}$ & tn & tn & tn & 12.900 \\
\hline $5 \mathrm{MST}$ & tn & tn & tn & 13.229 \\
\hline $6 \mathrm{MST}$ & tn & tn & tn & 13.174 \\
\hline $7 \mathrm{MST}$ & $*$ & tn & $\operatorname{tn}$ & 13.194 \\
\hline $8 \mathrm{MST}$ & $*$ & tn & $\operatorname{tn}$ & 13.663 \\
\hline $9 \mathrm{MST}$ & $*$ & tn & $\operatorname{tn}$ & 14.713 \\
\hline $10 \mathrm{MST}$ & $*$ & tn & $\operatorname{tn}$ & 15.686 \\
\hline
\end{tabular}

Keterangan: tn : Tidak nyata pada uji F 5\%; * Nyata pada uji F 5\%, ** : Sangat nyata pada uji F 5\%; MST : Minggu Setelah Tanam; Semua data merupakan hasil transformasi $\sqrt{(x+1)}$

Eksplan tunas in vitro nepenthes yang digunakan dalam penelitian ini berasal dari biji yang dikecambahkan di media $1 / 2$ MS, eksplan tersebut telah berumur \pm 1.5 tahun sejak 
dikecambahkan. Kontaminasi pada kultur terjadi pada minggu kedua sebesar $0.8 \%$, meningkat pada minggu keempat sebesar $4.0 \%$. Tingkat kontaminasi tertinggi terjadi pada minggu ketujuh sebesar $6.4 \%$.

Sitokinin memberikan pengaruh yang nyata terhadap waktu inisiasi akar, waktu inisiasi daun dan jumlah akar pada 5-6 MST, 8 MST dan 10 MST. Sitokinin memberikan pengaruh sangat nyata pada jumlah akar pada 7 dan 9 MST.

Kontaminasi yang ditemukan selama pengamatan yaitu kontaminasi cendawan dan bakteri. Kultur yang terkontaminasi cendawan ditandai dengan adanya benang-benang hifa maupun spora cendawan pada eksplan, botol kultur ataupun media, sedangkan eksplan yang terkontaminasi bakteri ditandai dengan munculnya lendir pada eksplan maupun pada media. Menurut Gunawan (1992), inisiasi kultur yang bebas kontaminasi merupakan langkah yang sangat penting.

Kontaminan akan tumbuh dengan cepat pada media yang mengandung gula, vitamin dan mineral bila faktor kontaminasi tidak dihilangkan. Eksplan dapat mati akibat langsung dari serangan cendawan atau bakteri, atau secara tidak langsung akibat persenyawaan toksik yang diproduksi cendawan atau bakteri. Terjadinya kontaminasi pada eksplan diduga karena beberapa hal, antara lain kurang sterilnya ruang tanam maupun laminar air flow cabinet saat penanaman, peralatan yang digunakan tidak steril dan kurangnya perlakuan sterilisasi pada ruang kultur.
Rekapitulasi sidik ragam menunjukkan pengaruh NAA nyata terhadap jumlah daun dan jumlah tunas. NAA memberikan pengaruh yang nyata pada 10 MST terhadap jumlah daun yang terbentuk. NAA juga memberikan pengaruh yang nyata pada 7-10 MST terhadap jumlah tunas.

Waktu Inisiasi Ploriferasi Tunas. Berdasarkan hasil sidik ragam, kombinasi NAA dan sitokinin tidak memberikan pengaruh nyata pada waktu inisiasi ploriferasi tunas Nepenthes mirabilis baik secara tunggal maupun kombinasi. Waktu inisiasi ploriferasi tunas tercepat pada media tanpa penambahan zat pengatur tumbuh yaitu 5.2 HST, sedangkan waktu inisiasi ploriferasi tunas terlama pada media dengan pemberian BAP sebesar $2.5 \mathrm{mg} / \mathrm{l}$ yaitu 13.0 HST. Pemberian zat pengatur tumbuh menyebabkan waktu ploriferasi tunas menjadi lebih lama terlihat dari Tabel 2, dimana pemberian zat pengatur tumbuh berupa sitokinin maupun auksin tidak memberikan pengaruh waktu inisiasi tunas lebih cepat dibandingkan dengan tanpa pemberian zat pengatur tumbuh.

Waktu inisiasi ploriferasi tunas dapat dilihat saat pengamatan harian beberapa hari setelah tanam (HST) yang ditandai dengan munculnya daun baru pada ruas atau ketiak daun. Tunas ini akan tumbuh dan mengeluarkan daun dan kantong baru setelah daun pertama. Dalam satu tanaman, tunas dapat tumbuh lebih dari satu sehingga pengamatan jumlah tunas dilakukan tiap minggunya setelah tunas pertama tumbuh.

Tabel 2. Pengaruh pemberian BAP dan NAA terhadap wInisiasi ploriferasi tunas dan waktu inisiasi kantong Nepenthes mirabilis secara in vitro

\begin{tabular}{lcc}
\hline Perlakuan & $\begin{array}{c}\text { Waktu Ploriferasi } \\
\text { Inisiasi Tunas } \\
\text { (HST) }\end{array}$ & $\begin{array}{c}\text { Waktu Inisiasi Kantong } \\
\text { (HST) }\end{array}$ \\
\hline $\begin{array}{l}\text { Sitokinin }(\mathrm{mg} / \mathrm{l}) \\
0\end{array}$ & 5.2 & 11.8 \\
BAP & & \\
2.5 & 13.0 & 19.3 \\
5.0 & 11.6 & 21.7 \\
$2 \mathrm{iP}$ & & 17.4 \\
2.5 & 5.3 & 13.8 \\
5.0 & 8.3 & 17.4 \\
Kinetin & & 13.6 \\
2.5 & 11.0 & 18.7 \\
5.0 & 11.1 & 14.2 \\
\hline NAA (mg/l) & & 19.4 \\
1.0 & 8.3 & \\
2.0 & 21.607 & 19.789 \\
\hline KK $(\%)$ & & \\
\hline
\end{tabular}

Pemberian zat pengatur tumbuh tidak memberikan pengaruh terhadap waktu inisiasi ploriferasi tunas diduga adanya sitokinin endogen yang cukup tinggi di dalam tanaman induk 
Nepenthes mirabilis yang dijadikan eksplan, sehingga pemberian sitokinin akan menghambat inisiasi ploriferasi tunas.

Menurut Mufa'adi (2003) bahwa tanaman terpacu untuk lebih cepat melakukan multiplikasi tunas disebabkan oleh pemberian sitokinin BAP. Pada penelitian ini BAP dan hormon sitokinin yang lain tidak menyebabkan perbedaan yang nyata untuk menginisiasi ploreferasi tunas sehingga tanpa pemberian sitokinin pun sudah dapat menginisiasi tunas nepenthes mirabilis lebih cepat. Menurut Sudarmonowati et al. (2002), apabila tanpa hormon tidak berpengaruh nyata maka tidak diperlukan penggunaan BAP sehingga biaya produksi akan jauh lebih murah.

Waktu Inisiasi Kantong. Waktu inisiasi kantong dapat dilihat beberapa hari setelah tanam (HST). Pengamatan waktu inisiasi kantong diawali dengan tumbuhnya daun baru yang disusul pembentukan kantong, kantong yang telah terbuka pada daun baru merupakan awal dari pengamatan waktu inisiasi kantong. Pengamatan jumlah kantong selanjutnya dilakukan setiap minggu setelah kantong pertama terbuka di setiap tanaman.

Berdasarkan hasil sidik ragam, kombinasi NAA dan sitokinin tidak memberikan pengaruh nyata pada waktu inisiasi kantong Nepenthes mirabilis baik secara tunggal maupun kombinasi. Waktu inisiasi kantong tercepat pada media tanpa penambahan zat pengatur tumbuh yaitu pada 11.8 HST, sedangkan waktu inisiasi kantong terlama pada media dengan pemberian BAP $5 \mathrm{mg} / \mathrm{l}$ yaitu pada 21.7 HST.

Pemberian zat pengatur tumbuh selain menyebabkan waktu inisiasi tunas lebih lama juga menyebabkan waktu inisiasi kantong menjadi lebih lama pula. Hal ini terlihat dari Tabel 2, dimana pemberian zat pengatur tumbuh berupa sitokinin maupun auksin tidak berpengaruh nyata waktu inisiasi kantong lebih cepat dibandingkan dengan tanpa pemberian zat pengatur tumbuh. Hal ini terjadi sejalan dengan pembentukan tunas, dimana waktu pembentukan tunas yang lebih cepat mempengaruhi waktu pembentukan kantong yang lebih cepat pula.

Waktu Inisiasi Daun. Berdasarkan hasil sidik ragam, pemberian kombinasi NAA dan sitokinin tidak memberikan pengaruh yang nyata terhadap waktu inisiasi akar Nepenthes mirabilis. Pengaruh nyata diperoleh dari pemberian sitokinin secara tunggal. Pemberian sitokinin berupa 2iP 5 $\mathrm{mg} / \mathrm{l}$ mampu menghasilkan waktu inisiasi daun tercepat yaitu 4.0 HST, sedangkan pemberian sitokinin berupa BAP 5 ppm menghasilkan waktu inisiasi terlama yaitu 13.0 HST.

Waktu inisiasi daun diamati beberapa hari setelah tanam (HST). Pengamatan waktu inisiasi daun dapat dilihat dengan munculnya daun baru melalui ujung tunas apikal maupun tunas lateral. Setelah waktu inisiasi daun diketahui maka dilanjutkan dengan pengamatan jumlah daun setiap minggunya.

Waktu Inisiasi Akar. Berdasarkan hasil sidik ragam, pemberian kombinasi NAA dan Sitokinin tidak berpengaruh nyata terhadap waktu inisiasi akar Nepenthes mirabilis. Pengaruh yang nyata diperoleh dari pemberian sitokinin secara tunggal.

Tabel 3. Pengaruh pemberian sitokinin terhadap waktu inisiasi akar dan waktu inisiasi daun Nepenthes mirabilis secara in vitro

\begin{tabular}{ccc}
\hline $\begin{array}{c}\text { Sitokinin } \\
(\mathrm{mg} / \mathrm{l})\end{array}$ & $\begin{array}{c}\text { Waktu Inisiasi Akar } \\
(\mathrm{HST})\end{array}$ & $\begin{array}{c}\text { Waktu Inisiasi Daun } \\
(\mathrm{HST})\end{array}$ \\
\hline 0 & $24.9 \mathrm{a}$ & $5.7 \mathrm{abc}$ \\
BAP & & $11.1 \mathrm{ab}$ \\
2.5 & $6.2 \mathrm{bc}$ & $13.5 \mathrm{a}$ \\
5.0 & $0.0 \mathrm{c}$ & \\
$2 \mathrm{PP}$ & & $5.8 \mathrm{abc}$ \\
2.5 & $14.2 \mathrm{abc}$ & $4.0 \mathrm{c}$ \\
5.0 & $0.0 \mathrm{c}$ & $10.9 \mathrm{abc}$ \\
Kinetin & $13.5 \mathrm{abc}$ & $5.4 \mathrm{bc}$ \\
2.5 & $19.0 \mathrm{ab}$ & 13.931 \\
5.0 & 30.539 & \\
KK $(\%)$ & & $\mathrm{pac}$ \\
\hline
\end{tabular}

Keterangan: Nilai yang diikuti oleh huruf yang sama pada kolom yang sama tidak berbeda nyata pada uji DMRT 5\% Data merupakan hasil transformasi $\sqrt{ }(x+1)$

Pemberian sitokinin berupa BAP 2.5 ppm mampu menghasilkan waktu inisiasi akar tercepat. Media tanpa sitokinin justru memperlambat waktu 281 inisiasi akar.Pada pengamatan selama 10 minggu inisiasi akar tidak terjadi pada media dengan penambahan BAP dan 2iP sebesar 5 ppm.

Agus Setyo Yudhanto dan Ni Made Armini Wiendi 
Waktu inisiasi akar dapat dilihat beberapa hari setelah tanam (HST). Ditandai dengan terbentuknya bulu-bulu akar dan terlihat ujung akar berwarna putih. Setelah diketahui waktu inisiasi akar maka dilanjutkan dengan pengamatan jumlah akar yang dilakukan tiap minggunya.

Jumlah Tunas. Berdasarkan sidik ragam, pemberian kombinasi NAA dan sitokinin tidak memberikan pengaruh nyata terhadap jumlah tunas. Pengaruh yang nyata diperoleh dari pemberian NAA secara tunggal pada minggu 7-10 MST. Pemberian NAA sebesar 1 ppm menghasilkan jumlah tunas terbanyak yaitu sebesar 5.2 tunas/eksplan pada pengamatan 10 MST.

Tabel 4. Pengaruh pemberian NAA terhadap rata-rata jumlah tunas Nepenthes mirabilis pada 2-10 MST secara in vitro

\begin{tabular}{lccccc}
\hline NAA (mg/l) & \multicolumn{5}{c}{ Jumlah Tunas } \\
\cline { 2 - 6 } & \multicolumn{5}{c}{ Waktu (MST) } \\
\cline { 2 - 6 } & 1.7 & 3.0 & 6 & 3.6 & 10 \\
\hline 1.0 & 1.1 & 1.8 & 2.1 & $2.2 \mathrm{~b}$ & $2.5 \mathrm{~b}$ \\
2.0 & 14.3 & 12.9 & 13.2 & 13.7 & 15.7 \\
\hline KK $(\%)$ & & & \multicolumn{5}{c}{ a } & \\
\hline
\end{tabular}

Keterangan: Nilai yang diikuti oleh huruf yang sama pada kolom yang sama tidak berbeda nyata pada uji DMRT 5\%, data merupakan hasil transformasi $\sqrt{(x+1)}$

Jumlah Daun. Berdasarkan hasil sidik ragam, kombinasi NAA dan sitokinin tidak memberikan pengaruh nyata pada jumlah daun Nepenthes mirabilis baik secara tunggal maupun kombinasi. Pemberian media BAP sebesar 2.5 ppm mampu menghasilkan jumlah daun terbesar sebanyak 22.8 selama 10 MST.

Peningkatan pemberian sitokinin maupun

NAA terbukti menurunkan jumlah daun nepenthes. Hal ini dapat dilihat pada tabel dimana rata-rata jumlah daun nepenthes pada media dengan sitokinin $2.5 \mathrm{ppm}$ lebih besar dibandingkan dengan media dengan sitokinin 5 ppm, begitu juga dengan pemberian NAA 1 ppm menunjukkan jumlah daun yang lebih besar dibandingkan dengan pemberian NAA 2 ppm.

Tabel 5. Pengaruh pemberian NAA dan sitokinin terhadap rata-rata jumlah daun Nepenthes mirabilis pada 210 MST secara in vitro

\begin{tabular}{|c|c|c|c|c|c|}
\hline \multirow{3}{*}{ Perlakuan } & \multicolumn{5}{|c|}{ Jumlah daun } \\
\hline & \multicolumn{5}{|c|}{ Waktu (MST) } \\
\hline & 2 & 4 & 6 & 8 & 10 \\
\hline \multicolumn{6}{|l|}{ Sitokinin $(\mathrm{mg} / \mathrm{l})$} \\
\hline 0 & 1.0 & 3.3 & 5.6 & 7.9 & 11.8 \\
\hline \multicolumn{6}{|l|}{ BAP } \\
\hline 2.5 & 1.1 & 3.7 & 11.6 & 17.8 & 22.8 \\
\hline 5.0 & 1.3 & 4.7 & 10.7 & 15.3 & 20.0 \\
\hline \multicolumn{6}{|l|}{$2 \mathrm{iP}$} \\
\hline 2.5 & 1.8 & 4.7 & 7.1 & 12.4 & 14.6 \\
\hline 5.0 & 1.4 & 2.7 & 8.0 & 11.0 & 13.5 \\
\hline \multicolumn{6}{|l|}{ Kinetin } \\
\hline 2.5 & 1.3 & 5.8 & 11.8 & 15.0 & 17.7 \\
\hline 5 & 1.2 & 4.0 & 7.8 & 11.0 & 13.4 \\
\hline \multicolumn{6}{|l|}{ NAA (mg/l) } \\
\hline 1.0 & 1.3 & 4.7 & 10.4 & 15.2 & 19.6 \\
\hline 2.0 & 1.3 & 3.5 & 7.4 & 10.6 & 12.8 \\
\hline KK (\%) & 8.1 & 13.6 & 15.9 & 17.2 & 17.2 \\
\hline
\end{tabular}

Jumlah Kantong. Berdasarkan hasil sidik ragam, kombinasi NAA dan sitokinin tidak memberikan pengaruh nyata pada jumlah kantong Nepenthes mirabilis baik secara tunggal maupun kombinasi. Pemberian kinetin sebesar $2.5 \mathrm{ppm}$ mampu menghasilkan jumlah kantong sebanyak 12.6 selama 10 MST.

Peningkatan pemberian sitokinin maupun NAA terlihat menurunkan jumlah kantong yang diduga menghambat pertumbuhan tanaman. 
Pertumbuhan terhambat dengan semakin kecilnya penambahan zat pengatur tumbuh di dalam media jumlah kantong yang terbentuk sejalan dengan

Tabel 6. Pengaruh Pemberian NAA dan Sitokinin Terhadap Rata-rata Jumlah Kantong Nepenthes mirabilis pada 2-10 MST secara in vitro

\begin{tabular}{|c|c|c|c|c|c|}
\hline \multirow{3}{*}{ Perlakuan } & \multicolumn{5}{|c|}{ Jumlah Kantong } \\
\hline & \multicolumn{5}{|c|}{ Waktu (MST) } \\
\hline & 2 & 4 & 6 & 8 & 10 \\
\hline \multicolumn{6}{|l|}{$\begin{array}{l}\text { Sitokinin } \\
(\mathrm{mg} / \mathrm{l})\end{array}$} \\
\hline 0 & 0.4 & 2.8 & 4.5 & 6.3 & 8.6 \\
\hline \multicolumn{6}{|l|}{ BAP } \\
\hline 2.5 & 0.0 & 1.5 & 4.5 & 6.8 & 9.5 \\
\hline 5.0 & 0.4 & 1.6 & 4.2 & 7.0 & 10.1 \\
\hline \multicolumn{6}{|l|}{$2 \mathrm{iP}$} \\
\hline 2.5 & 0.3 & 2.4 & 5.2 & 8.9 & 11.4 \\
\hline 5.0 & 0.6 & 1.6 & 3.8 & 7.0 & 8.8 \\
\hline \multicolumn{6}{|l|}{ Kinetin } \\
\hline 2.5 & 0.5 & 2.4 & 6.9 & 10.5 & 12.6 \\
\hline 5.0 & 0.7 & 1.8 & 4.5 & 7.1 & 8.8 \\
\hline \multicolumn{6}{|c|}{ NAA(mg/l) } \\
\hline 1.0 & 0.4 & 2.2 & 5.5 & 9.1 & 12.0 \\
\hline 2.0 & 0.4 & 1.8 & 4.1 & 6.2 & 7.9 \\
\hline KK (\%) & 7.6 & 13.1 & 14.6 & 17.0 & 18.2 \\
\hline
\end{tabular}

Jumlah Akar. Berdasarkan hasil sidik ragam, pemberian kombinasi NAA dan sitokinin tidak memberikan pengaruh yang nyata terhadap jumlah akar. Pengaruh yang nyata diperoleh dari pemberian sitokinin secara tunggal pada $5,6,8$ dan 10 MST serta berpengaruh sangat nyata pada 7 dan 9 MST. Pemberian sitokinin berupa kinetin sebesar 5 ppm menghasilkan jumlah akar terbanyak yaitu sebanyak 14.1 akar/eksplan pada waktu $10 \mathrm{MST}$, sedangkan pemberian sitokinin berupa 2ip dan BAP sebesar 5 ppm tidak menghasikan akar sampai pengamatan 10 MST.
Pemberian sitokinin berupa BAP dan 2iP pada tanaman nepenthes tidak menunjukkan penambahan jumlah akar yang signifikan selama 10 minggu pengamatan. Pemberian BAP dan $2 \mathrm{iP}$ lebih dari $2.5 \mathrm{ppm}$ terlihat menghambat pertumbuhan akar. Berbeda dengan pemberian BAP dan 2 iP pemberian kinetin justru memberikan jumlah akar yang lebih banyak. Peningkatan pemberian kinetin hingga 5 ppm mampu meningkatkan jumlah akar hingga 14.1 akar/eksplan.

Tabel 7. Pengaruh Pemberian Sitokinin Terhadap Rata-rata Jumlah Akar Nepenthes mirabilis pada 2-10 MST secara in vitro

\begin{tabular}{|c|c|c|c|c|c|}
\hline \multirow{3}{*}{ Sitokinin (mg/l) } & \multicolumn{5}{|c|}{ Jumlah akar } \\
\hline & \multicolumn{5}{|c|}{ Waktu (MST } \\
\hline & 4 & 6 & 8 & 9 & 10 \\
\hline 0 & $0.7 \mathrm{ab}$ & $3.2 \mathrm{ab}$ & $6.6 \mathrm{a}$ & $8.2 \mathrm{ab}$ & $9.8 \mathrm{ab}$ \\
\hline \multicolumn{6}{|l|}{ BAP } \\
\hline 2.5 & $0.0 \mathrm{~b}$ & $0.2 \mathrm{c}$ & $0.8 b$ & $1.0 \mathrm{c}$ & $1.2 \mathrm{c}$ \\
\hline 5.0 & $0.0 \mathrm{~b}$ & $0.0 \mathrm{c}$ & $0.0 \mathrm{~b}$ & $0.0 \mathrm{c}$ & $0.0 \mathrm{c}$ \\
\hline \multicolumn{6}{|l|}{$2 \mathrm{iP}$} \\
\hline 2.5 & $0.8 \mathrm{ab}$ & $0.8 \mathrm{abc}$ & $2.8 \mathrm{ab}$ & $4.1 \mathrm{abc}$ & $5.3 \mathrm{ab}$ \\
\hline 5.0 & $0.0 \mathrm{~b}$ & $0.0 \mathrm{c}$ & $0.0 \mathrm{c}$ & $0.0 \mathrm{c}$ & $0.0 \mathrm{c}$ \\
\hline \multicolumn{6}{|l|}{ Kinetin } \\
\hline 2.5 & $0.2 \mathrm{ab}$ & $0.4 \mathrm{bc}$ & $0.4 b$ & $1.3 \mathrm{bc}$ & $2.1 \mathrm{bc}$ \\
\hline 5.0 & $1.5 \mathrm{a}$ & $3.6 \mathrm{a}$ & $8.8 \mathrm{a}$ & $12.1 \mathrm{a}$ & $14.1 \mathrm{a}$ \\
\hline KK (\%) & 8.320 & 13.841 & 19.475 & 20.986 & 22.538 \\
\hline
\end{tabular}

Keterangan: Nilai yang diikuti oleh huruf yang sama pada kolom yang sama tidak berbeda nyata pada uji DMRT 5\% Data merupakan hasil transformasi $\sqrt{(x+1)}$ 


\section{KESIMPULAN}

Interaksi antara NAA dengan sitokinin tidak memberikan pengaruh nyata pada semua pengamatan. Pengaruh nyata didapat dari pemberian NAA atau sitokinin secara tunggal. Pemberian NAA dengan konsentrasi $1 \mathrm{mg} / \mathrm{l}$ terbukti mampu memberikan jumlah tunas terbanyak (5.2 tunas) selama 10 minggu, sedangkan pemberian BAP dengan konsentrasi $2.5 \mathrm{mg} / \mathrm{l}$ terbukti mampu memberikan waktu inisiasi akar tercepat (6.2 HST) selama 10 minggu.

Pemberian NAA berpengaruh nyata pada pengamatan jumlah tunas 7-10 MST, sedangkan pemberian sitokinin berpengaruh sangat nyata pada pengamatan jumlah akar pada 7 dan 9 MST. Pemberian 2iP dengan konsentrasi $5 \mathrm{mg} / \mathrm{l}$ terbukti mampu memberikan waktu inisiasi daun tercepat (4.0 HST) selama 10 minggu, sedangkan pemberian kinetin dengan konsentrasi $5 \mathrm{mg} / \mathrm{l}$ terbukti mampu memberikan jumlah akar terbanyak (14.1) selama 10 minggu pengamatan.

\section{DAFTAR PUSTAKA}

Cheek, M., Jebb, M. 2001. Flora Malesiana Series I. National Herbarium Netherland, Universiteit Leiden Brach: Leiden Brach.
Gunawan, L. W. 1992. Teknik Kultur Jaringan Tanaman. Departemen Pendidikan Tinggi. Pusat Antar Universitas Bioteknologi. Bogor (ID) : Institut Pertanian Bogor.

Mansur, M. 2006. Nepenthes Kantong Semar yang Unik. Jakarta (ID) : Penebar Swadaya.

Mufa'adi, A. 2003. pengaruh kombinasi zat pengatur tumbuh bap dan iaa terhadap pertumbuhan dan perkembangan tanaman daun dewa (Gynura procumbens (Back.)) dalam kultur in vitro. [skripsi]. Bogor (ID): Institut Pertanian Bogor.

Phillipps, A., Lamb, A.1996. Pitcer Plant of Borneo. Kuala Lumpur (MAL) : United Selangor Press.

Rasco Jr., Maquilan, M.A.D. 2005. Initial studies on in vitro germination and early seedling growth of nepenthes truncata macf. Carnivorous Plant Newslatter. (34):51.

Sundorowati, E., Hartati, R., Taryana, T. 2002. Produksi tunas, regenerasi dan evaluasi hasil ubi kayu (manihot esculenta) indonesia asal kultur jaringan di lapang [Internet]. [Diunduh 2007 Nov 14]. Tersedia pada http://www.unri.ac.id/jurnal/jurnal_natur/ vol4(2)/enny.pdf 